\title{
Relaxin protects cardiac muscle cells from hypoxia/reoxygenation injury: involvement of the Notch-1 pathway
}

\author{
Giulia Boccalini, Chiara Sassoli, Lucia Formigli, Daniele Bani, and Silvia Nistri ${ }^{1}$ \\ Department of Experimental and Clinical Medicine, Section of Anatomy and Histology, Research Unit of \\ Histology and Embryology, University of Florence, Florence, Italy
}

\begin{abstract}
In animal models, the cardiotropic hormone relaxin has been shown to protect the heart against ischemia and reperfusion-induced damage, acting by multiple mechanisms that primarily involve the coronary vessels. This in vitro study evaluates whether relaxin also has a direct protective action on cardiac muscle cells. H9c2 rat cardiomyoblasts and primary mouse cardiomyocytes were subjected to hypoxia and reoxygenation. In some experiments, relaxin was added preventatively before hypoxia; in others, at reoxygenation. To elucidate its mechanisms of action, we focused on Notch-1, which is involved in heart pre- and postconditioning to ischemia. Inactivated RLX was used as negative control. Relaxin $\left(17 \mathrm{nmol} / \mathrm{L}, \mathrm{EC}_{50} 4.7 \mathrm{nmol} / \mathrm{L}\right)$, added $24 \mathrm{~h}$ before hypoxia or at reoxygenation, protected against cardiomyocyte injury. In fact, relaxin significantly increased cell viability (assayed by trypan blue and 3-(4,5-dimethylthiazol-2-yl)2,5-diphenyl tetrazolium bromide), decreased apoptosis (assayed by TUNEL and bax/bcl-2 ratio), and reduced nitroxidative damage (assayed by nitrotyrosine expression and 8-hydroxy-deoxyguanosine levels). These effects were partly attributable to the ability of relaxin to upregulate Notch-1 signaling; indeed, blockade of Notch-1 activation with the specific inhibitor DAPT reduced relaxin-induced cardioprotection during hypoxia and reoxygenation. This study adds new mechanistic insights on the cardioprotective role of relaxin on ischemic and oxidative damage.Boccalini, G., Sassoli, C., Formigli, L., Bani, D., Nistri, S. Relaxin protects cardiac muscle cells from hypoxia/reoxygenation injury: involvement of the Notch-1 pathway. FASEB J. 29, 239-249 (2015). www.fasebj.org
\end{abstract}

Key Words: H9c2 - cardiomyocytes $\cdot$ RXFP1 $\cdot$ DAPT $\cdot$ oxidative injury

Cardiovascular disease is the leading cause of death in modern society worldwide (1). In particular, cardiac

Abbreviations: 8-OHdG, 8-hydroxy-2'-deoxyguanosine; DAPT, $N-[N-(3,5$ difluorophenacetyl)-l-alanyl $]-S$-phenylglycine t-butyl ester; FBS, fetal bovine serum; $\mathrm{H}+\mathrm{R}$, hypoxia followed by reoxygenation; $I / R$, ischemia/reperfusion; iRLX, inactivated RLX; MTT, 3-(4,5-dimethylthiazol-2-yl)-2,5-diphenyl tetrazolium bromide; Notch-ICD, Notch intracellular domain; NT, nitrotyrosine; OD, optical density; RLX, relaxin; ROI, region of interest; ROS, reactive oxygen species; RXFP1, relaxin family peptide receptor 1 dysfunction caused by nonlethal myocardial infarction remains one of the most challenging clinical problems. The pathogenic occurrences in the infarcted heart are dependent on ischemia/reperfusion $(I / R)$. The mechanisms of $\mathrm{I} / \mathrm{R}$ injury are complex and involve multiple events, basically nitroxidative stress $(2,3)$ and inflammation (4), that play a key role in the progression of cardiac damage and in the development of myocardial fibrosis and heart failure (5). Hence, there is a major interest in the identification of new therapeutic agents that can prevent or reduce I/R-induced myocardial injury. In this context, the hormone relaxin (RLX) emerges as a feasible candidate. Best known for its effects on reproduction (6), RLX has been validated as a bona fide cardiovascular hormone (7-9). Studies in rats have shown that immunoreactive RLX is produced by cultured atrial cardiomyocytes (10) and that RLX receptors are expressed by the atrial and ventricular myocardium (11) and ventricular cardiomyocytes (12). RLX is capable of enhancing cardiac blood perfusion by dilating the preexisting coronary vessels (13) and promoting neo-angiogenesis $(14,15)$. The increased blood supply to the heart induced by RLX, accompanied by its clear-cut anti-inflammatory (16-18) and antifibrotic effects $(15,19-23)$, may account for the protective action of RLX shown in animal models of cardiac I/R. In these models, RLX markedly reduces several myocardial injury parameters, the extension of nonviable myocardium and fibrosis, thereby improving cardiac contractile performance (15, 18, 20, 24-26). Whether RLX may also behave as a direct protective factor for cardiomyocytes is a tantalizing but poorly explored matter. Indeed, this hypothesis is corroborated by the findings that ventricular cardiomyocytes express the specific RLX receptor RXFP1 (12) and that RLX protects cardiomyocytes against oxidative stress-induced apoptosis in vitro (27). A strictly related issue to investigate is related to the intracellular mechanisms by which RLX may exert cardioprotection. In this context, the Notch-1 pathway, which is involved in ischemic preconditioning and postconditioning of the heart $(28,29)$ and in the

\footnotetext{
${ }^{1}$ Correspondence: Department of Experimental and Clinical Medicine, Section of Anatomy and Histology, Research Unit of Histology and Embryology, University of Florence, viale G. Pieraccini, 6, I-50139 Florence, Italy. E-mail: silvia.nistri@ unifi.it

doi: $10.1096 /$ fj.14-254854
} 
reduction of I/R-induced cardiac nitroxidative stress (30), holds a pivotal place. Notch-1 is a transmembrane receptor that, once bound to its ligand, undergoes proteolytic cleavages managed sequentially by ADAM 10 metalloprotease and the $\gamma$-secretase complex. These events allow the release of the intracellular domain of Notch (Notch-ICD) that translocates to the nucleus to control transcription of specific target genes (31). The relationship between RLX and Notch-1 is supported by the recent demonstration that RLX prevents the TGF$\beta$-induced transition of cardiac fibroblasts to myofibroblasts by activation of Notch-1 pathway (23) .

The present study was designed to investigate the possible protective actions of RLX on cardiac muscle cells using an in vitro model of $\mathrm{I} / \mathrm{R}$, i.e., hypoxia followed by reoxygenation $(\mathrm{H}+\mathrm{R})$, and to evaluate the possible involvement of the Notch-1 pathway.

\section{MATERIALS AND METHODS}

\section{Ethics statements}

Animal handling and use complied with the European Community guidelines for animal care (DL 116/92, application of the European Communities Council Directive of November 24, 1986; 86/609/EEC) and were approved by the Committee for Animal Care and Experimental Use of the University of Florence. The ethical policy of the University of Florence conforms to the Guide for the Care and Use of Laboratory Animals of the US National Institutes of Health (Publication No. 85-23, revised 1996; University of Florence assurance no. A5278$01)$. The animals had free access to food and water and were housed on a $12 \mathrm{~h}$ light/dark cycle at $22^{\circ} \mathrm{C}$ room temperature. The experiments were designed to minimize pain and the number of animals used. Killing was carried out by decapitation.

\section{Cell culture and treatments}

H9c2 embryonic rat myocardium-derived cells, a wellcharacterized and widely used cell line to study myocardial cell ischemia (32), were obtained from European Collection of Cell Cultures (ECACC, Salisbury, United Kingdom). They were cultured in DMEM (Sigma-Aldrich, Milan, Italy) supplemented with $10 \%$ heat-inactivated fetal bovine serum (FBS; Invitrogen, Carlsbad, CA, USA), $2 \mathrm{mM}$ glutamine, $250 \mathrm{U} / \mathrm{ml}$ penicillin $\mathrm{G}$, and $250 \mu \mathrm{g} / \mathrm{ml}$ streptomycin (Sigma-Aldrich), in a humidified atmosphere with $5 \% \mathrm{CO}_{2}$ at $37^{\circ} \mathrm{C}$. Primary cultures of mouse ventricular immature cardiomyocytes were prepared from hearts of 1-d-old newborn CD1 albino mice (Harlan, Correzzana, Italy), as previously described (33). Briefly, hearts were excised, and the ventricles were minced and digested at $37^{\circ} \mathrm{C}$ for $45 \mathrm{~min}$ in calcium-free 4-(2-hydroxyethyl)-1-piperazineethanesulfonic acid (HEPES)-buffered Hanks' solution, pH 7.4, containing $100 \mu \mathrm{g} /$ $\mathrm{ml}$ type II collagenase (Invitrogen). To reduce the harvest of nonmyocardial cells, the tissue lysate was filtered through a 70 $\mu \mathrm{m}$ cell strainer (Millipore, Billerica, MA, USA) and preplated for $1 \mathrm{~h}$. The myocyte-enriched cells remaining in suspension were seeded on collagen-precoated multiwell plates. Cardiomyocytes were cultured in DMEM containing 10\% horse serum, $5 \%$ FBS, $2 \mathrm{mM}$ glutamine, $250 \mathrm{U} / \mathrm{ml}$ penicillin $\mathrm{G}$, and $250 \mu \mathrm{g} / \mathrm{ml}$ streptomycin. In previous studies, these cells were characterized morphologically, immunophenotypically, and electrophysiologically $(33,34)$ and were shown to express the specific RLX family peptide receptor-1 (RXFP1) (34).

$\mathrm{H} 9 \mathrm{c} 2$ cells and primary cardiomyocytes were subjected to $\mathrm{H}+\mathrm{R}$, simulated in vitro by substrate starvation plus hypoxia followed by reoxygenation as previously described (35) with minor modifications. The cells were incubated in DMEM with no serum or glucose and placed in a hypoxic chamber saturated with a $0.1 \% \mathrm{O}_{2}, 5 \% \mathrm{CO}_{2}, \approx 95 \% \mathrm{~N}_{2}$ gaseous mix, humidified, and warmed at $37^{\circ} \mathrm{C}$, for $7 \mathrm{~h}$. At end hypoxia, the cells were reoxygenated for $2 \mathrm{~h}$ by incubation in normoxic conditions in glucose-containing, serum-free DMEM. Control normoxic cultures were also prepared. Cells were treated or not with human recombinant RLX (17 nmol/L), kindly provided by the RRCA Relaxin Foundation (Florence, Italy), administered in 2 different ways: in some experiments, RLX was added preventatively, i.e., $24 \mathrm{~h}$ before hypoxia and maintained for the whole duration of $\mathrm{H}+\mathrm{R}(\mathrm{RLX}+\mathrm{H}$. and $\mathrm{RLX}+\mathrm{H}+\mathrm{R})$; in other experiments, RLX was added at reoxygenation, concurrently with the peak of ROS generation $(\mathrm{H}+\mathrm{RLX}+\mathrm{R})$. The noted RLX dose was chosen as the most effective on the basis of preliminary dose-finding experiments $(5-50 \mathrm{nmol} / \mathrm{ml})$ performed on $\mathrm{H} 9 \mathrm{c} 2$ cell viability (data not shown). These data were also used to determine RLX EC $\mathrm{E}_{50}$.

As a control for specificity of the RLX effects on cell viability, some experiments [3-(4,5-dimethylthiazol-2-yl)-2,5-diphenyl tetrazolium bromide (MTT) assay] were performed using inactivated RLX (iRLX, $17 \mathrm{nmol} / \mathrm{L}$ ) in the place of authentic RLX. iRLX was obtained by blockade of functional arginine residues by reaction with cyclohexanedione followed by dialysis of the unbound reagent against distilled water, according to the method of Büllesbach and Schwabe (36). To test the effective lack of bioactivity of iRLX, we measured cAMP generation in human THP-1 cells constitutively expressing RXFP1, as previously described (37). These findings confirm that, at variance with authentic RLX, iRLX did not induce any cAMP rise in THP1 cells (data not shown). The effects of iRLX were evaluated at reperfusion, when authentic RLX showed the highest cell protection.

To investigate the role of the Notch-1 pathway in the mechanism of action of RLX, H9c2 cells were treated with $N$ [ $N$-(3,5 difluorophenacetyl)-l-alanyl]-S-phenylglycine $t$-butyl ester (DAPT; $5 \mu \mathrm{M}$, Sigma-Aldrich), a highly active $\gamma$-secretase inhibitor that blocks the generation of the Notch intracellular domain (Notch-ICD), the active proteolytic fragment of Notch-1 receptor that mediates its biological effects. At the end of the treatments, the cell cultures were photographed under a phasecontrast inverted microscope.

\section{Reverse transcription and real-time PCR}

To evaluate whether H9c2 cells express RXFP1 mRNA, $1 \mu \mathrm{g}$ total RNA, extracted with TRIzol Reagent (Invitrogen), was reverse transcribed and amplified with the SuperScript One-Step RT-PCR System (Invitrogen). After cDNA synthesis for $30 \mathrm{~min}$ at $55^{\circ} \mathrm{C}$, the samples were predenatured for $2 \mathrm{~min}$ at $94^{\circ} \mathrm{C}$ and then subjected to 38 cycles of PCR performed at $94^{\circ} \mathrm{C}$ for $15 \mathrm{~s}$, alternating with $57^{\circ} \mathrm{C}$ for $30 \mathrm{~s}$ and $72^{\circ} \mathrm{C}$ for $1 \mathrm{~min}$; the final extension step was performed at $72^{\circ} \mathrm{C}$ for $5 \mathrm{~min}$. The following rat gene-specific primers were used: RXFP1 (NM_ 201417.1), forward 5'-CGG ATG GGA TCT CCT CTC TT-3' and reverse 5'-GCG TGC TTC CTG TAC TCT CC-3'. PCR products were electrophoresed on a $2 \%$ agarose gel stained with ethidium bromide.

To quantify bcl-2 and bax gene expression, $1 \mu \mathrm{g}$ total RNA was reverse transcribed with the iScript cDNA Synthesis Kit (Biorad, Milan, Italy). Samples were incubated at $25^{\circ} \mathrm{C}$ for $5 \mathrm{~min}$ followed by $30 \mathrm{~min}$ at $42^{\circ} \mathrm{C}$ and $5 \mathrm{~min}$ at $85^{\circ} \mathrm{C}$. Appropriate negative controls were carried out. Quantitative real-time PCR was performed using iTaq Universal SYBR Green Supermix (Biorad) on an ABI Prism 7900 HT detection system (Applied Biosystems Foster City, CA, USA). PCR amplifications were performed in Optical 96-well plates (Applied Biosystems) on cDNA samples corresponding to a final RNA concentration of 
$10 \mathrm{ng}$. The relative quantitation values of targets were normalized to the endogenous GAPDH control gene. The primers used in the current study were chosen from previously published studies (38): bcl-2 (NM_016993.1) forward 5'-GCT ACG AGT GGG ATA CTG G-3' and reverse 5'-GTG TGC AGA TGC CGG TTC A-3'; bax (NM_ 017059.2), forward 5'-CTG CAG AGG ATG ATT GCT GA-3' ${ }^{\prime}$ and reverse $5^{\prime}$-GAT CAG CTC GGG CAC TTT AG-3'; and GAPDH (NM_017008.4), forward 5'-AAC GGC ACA GTC AAG GCT GA-3' and reverse 5'-ACG CCA GTA GAC TCC ACG ACA T-3'. Reaction conditions were as follows: $95^{\circ} \mathrm{C}$ for $1 \mathrm{~min}$, followed by 40 cycles at $95^{\circ} \mathrm{C}$ for $15 \mathrm{~s}$ alternating with $55^{\circ} \mathrm{C}$ for $1 \mathrm{~min}$ for bax and GAPDH or $57^{\circ} \mathrm{C}$ for $1 \mathrm{~min}$ for bcl-2. PCR amplifications were run in triplicate. Blank controls, consisting of no template (water), were performed in each run. Melting curves were carried out to confirm amplification of single sequences and absence of primer dimers. The results of the real-time PCR data were represented as Ct values, where Ct was defined as the PCR threshold cycle at which amplified product was first detected. Ct values were analyzed using the $2^{-\Delta \Delta \mathrm{Ct}}$ comparative method.

\section{Western blotting}

After treatments, H9c2 cells were lysed in cold buffer $(10 \mathrm{mM}$ Tris/HCl, pH 7.4, $10 \mathrm{mM} \mathrm{NaCl}, 1.5 \mathrm{mM}, \mathrm{MgCl}_{2}, 2 \mathrm{mM} \mathrm{Na} 2$ EDTA, $1 \%$ Triton X-100), added with $10 \times$ Sigmafast Protease Inhibitor cocktail tablets (Sigma-Aldrich). On centrifugation at $13,000 \times g$ for $20 \mathrm{~min}$ at $4^{\circ} \mathrm{C}$, the supernatants were collected, and the total protein content was measured spectrophotometrically using the micro-BCA Protein Assay Kit (Pierce, IL, USA). Forty micrograms of total proteins from cell lysates was electrophoresed by SDS-PAGE and blotted onto nitrocellulose membranes (Amersham, Cologno Monzese, Italy). The membranes were blocked with PBS containing $0.1 \%$ Tween (Sigma-Aldrich) and $5 \%$ bovine serum albumin (AT-PBS; Sigma-Aldrich) for $1 \mathrm{~h}$ at room temperature and incubated overnight at $4^{\circ} \mathrm{C}$ with rabbit monoclonal anti-Notch-1 antibody (1:2000; Abcam) and rabbit polyclonal anti-GAPDH antibody (1:1000; Cell Signaling Technology), assuming GAPDH as a control invariant protein. Specific bands were detected using rabbit peroxidase-labeled secondary antibodies (1:15,000; Vector Laboratories, Burlingame, CA, USA) and ECL chemiluminescent substrate (Bio-Rad, Milan, Italy). Densitometric analysis of the bands was performed using Scion Image Beta 4.0.2 image analysis software (Scion Corporation), and the values were normalized to GAPDH.

\section{Trypan blue viability assay}

The trypan blue exclusion method was used to further assess cell viability. H9c2 cells $\left(5 \times 10^{4}\right.$ per well $)$ and primary cardiomyocytes $\left(3-5 \times 10^{4}\right.$ per well, depending on the number of littermates and the overall yielding of the isolation procedure) were seeded in 24-well plates. At end treatments, the cells were gently harvested and mixed with $0.4 \%$ Trypan blue solution (Sigma-Aldrich); the resulting cell suspension was counted under a phase-contrast inverted microscope using a Burker chamber. The viable cells were expressed as percentage of the total counted cells.

\section{MTT viability assay}

Cell viability was measured using the MTT assay (Sigma-Aldrich). H9c2 cells $\left(5 \times 10^{4}\right.$ per well) and primary cardiomyocytes $\left(3-5 \times 10^{4}\right.$ per well $)$ were seeded in 24 -well plates. At end treatments, MTT stock solution was added to each well and incubated for $4 \mathrm{~h}$ at $37^{\circ} \mathrm{C}$. Dimethyl sulfoxide was added to each well to dissolve the formazan crystals. The plate was gently shaken for $10 \mathrm{~min}$ and was read at $550 \mathrm{~nm}$ on a plate reader. Optical density (OD) was assumed as an indicator of cell viability. This assay was also used for evaluation of $\mathrm{EC}_{50}$ on increasing RLX doses of 5,17 , and $50 \mathrm{nmol} / \mathrm{L}$, corresponding to $515 \pm 23$, $973 \pm 73$, and $550 \pm 27 \mathrm{OD}$, respectively.

\section{TUNEL assay}

H9c2 cells were grown on glass coverslips and subjected to the different treatments. Cell death was studied with the TUNEL assay for apoptosis, performed using a Klenow-FragEL DNA fragmentation detection kit (Calbiochem, San Diego, CA, USA), as reported in the manufacturer's instructions. TUNEL-positive nuclei were counted in 5 microscopic fields for each cell preparation. TUNEL apoptotic index was then expressed as the relative percentage of TUNEL-positive nuclei on the total number of methyl green-stained nuclei.

\section{Immunohistochemical localization of nitrotyrosine}

Nitrotyrosine (NT), an index of protein nitrosylation by harmful oxidants generated during inflammation, such as peroxynitrite, was determined by immunocytochemistry as described previously (39). H9c2 cells were grown on glass coverslips and subjected to the different treatments. The cells were fixed with formaldehyde for $10 \mathrm{~min}$ and then incubated with rabbit polyclonal anti-NT antibody (1:118; Upstate Biotechnology, Buckingham, United Kingdom) at $4^{\circ} \mathrm{C}$ overnight. The immune reaction was revealed by goat anti-rabbit IgG conjugated with biotin (1:200; Vector Laboratories), followed by incubation with ABC complex (1:200; Vector Laboratories). Negative controls were carried out by omitting the primary antibodies. Densitometric analysis of the intensity of NT was performed on digitized images using Scion Image Beta 4.0.2 in 20 regions of interest (ROI) of $100 \mu \mathrm{m}^{2}$ for each confocal stacks (at least 10).

\section{Determination of 8-hydroxy-2'-deoxyguanosine}

8-Hydroxy-2'-deoxyguanosine (8-OHdG) levels, an indicator of oxidative DNA damage, were determined in $\mathrm{H} 9 \mathrm{c} 2$ cells using the Highly Sensitive 8-OHdG Check (JaICA), according to the manufacturer's instructions. After treatment, the cells were 
collected with TRIzol Reagent (Invitrogen), and DNA was isolated according to the manufacturer's instructions. DNA was then subjected to enzymatic digestion with $10 \mathrm{IU}$ of P1 nuclease (Sigma-Aldrich) in $10 \mu \mathrm{l}$ and incubated for $1 \mathrm{~h}$ at $37^{\circ} \mathrm{C}$ with $5 \mathrm{IU}$ of alkaline phosphatase (Sigma-Aldrich) in $0.4 \mathrm{M}$ phosphate buffer, $\mathrm{pH}$ 8.8. All of the procedures were performed in the dark under argon. The mixture was filtered by an Amicon MicropureEZ filter (Millipore), and $50 \mu \mathrm{l}$ of each sample was used for 8 -OHdG determination. The values are expressed as nanograms 8-OHdG per nanogram total DNA.

\section{Confocal Immunofluorescence}

$\mathrm{H} 9 \mathrm{c} 2$ cells grown on glass coverslips were fixed with $0.5 \%$ buffered paraformaldehyde for $10 \mathrm{~min}$ at room temperature. After permeabilization with cold acetone for $3 \mathrm{~min}$, the fixed cells were blocked with $0.5 \%$ bovine serum albumin (SigmaAldrich) and 3\% glycerol in PBS for $20 \mathrm{~min}$ and then incubated overnight at $4^{\circ} \mathrm{C}$ with a rabbit monoclonal anti-Notch-1 antiserum (1:200; Abcam), recognizing both Notch-1 receptor and its activated form Notch- ICD. Immunoreactions were revealed by specific anti-rabbit Alexa Fluor 488-conjugated IgG (1:200; Molecular Probes, Eugene, OR, USA) for $1 \mathrm{~h}$ at room temperature. Negative controls were carried out by replacing the primary antibody with nonimmune serum; cross-reactivity of the secondary antibody was tested in control experiments in which primary antibodies were omitted. After washing, the immunolabeled cells were mounted with an antifade medium (Biomeda Gel Mount; Electron Microscopy Sciences, Foster City, CA, USA) and observed under a confocal Leica TCS SP5 microscope (Leica Microsystems, Mannheim, Germany) equipped with a $\mathrm{HeNe} / \mathrm{Ar}$ laser source for fluorescence measurements. Observations were performed using a Leica Plan Apo $63 \times / 1.43 \mathrm{NA}$ oil immersion objective. Series of optical sections $(1024 \times 1024$ pixels each; pixel size, $204.3 \mathrm{~nm}) 0.4 \mu \mathrm{m}$ in thickness were taken through the depth of the cells at intervals of $0.4 \mu \mathrm{m}$. Images were then projected onto a single "extended focus" image. Densitometric analysis of the intensity of Notch-ICD fluorescent signal was performed on digitized images using the Scion Image Beta
A

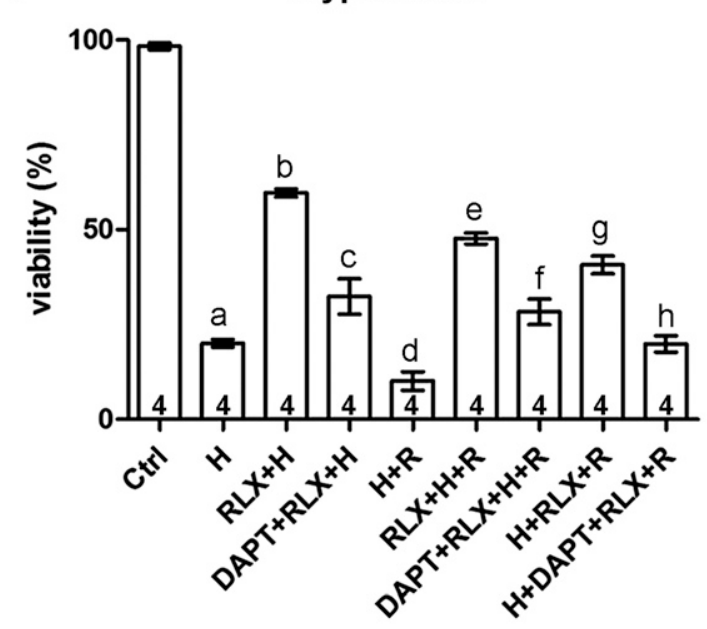

C

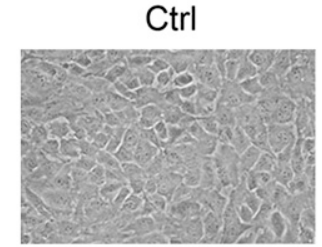

$\mathrm{H}$

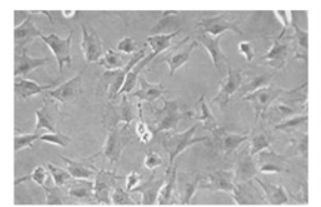

B

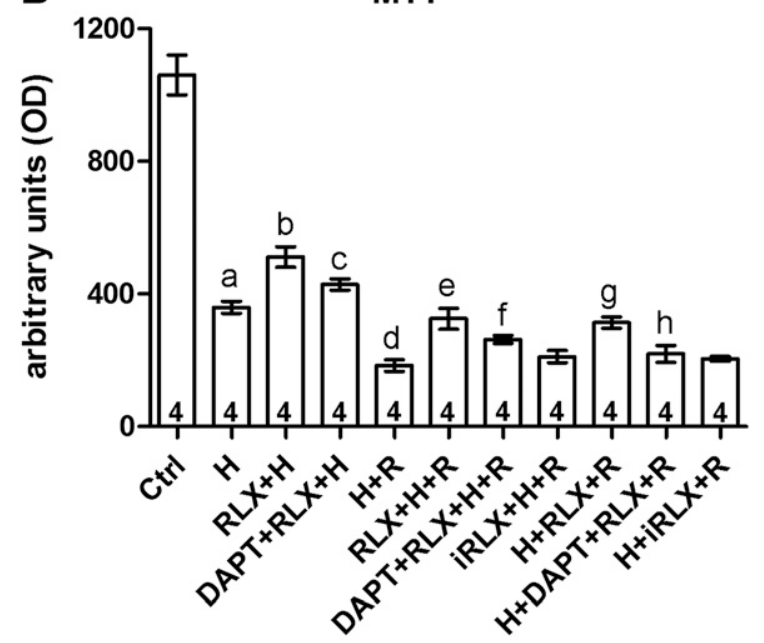

$\mathrm{RLX}+\mathrm{H}$

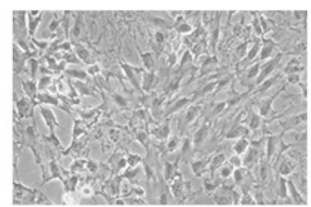

$\mathrm{DAPT}+\mathrm{RL} \mathrm{X}+\mathrm{H}$

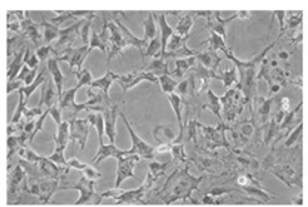

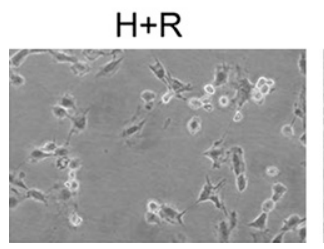
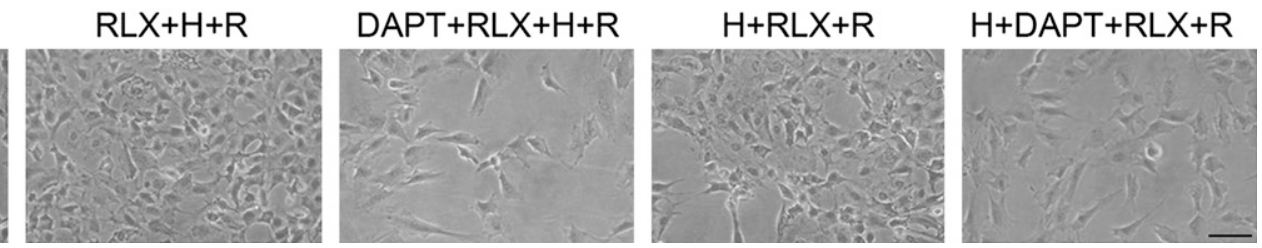

Figure 2. Evaluation of $\mathrm{H} 9 \mathrm{c} 2$ cell viability by trypan blue exclusion $(A)$ and MTT $(B)$ assay. Hypoxia $(\mathrm{H})$ and even more reoxygenation $(\mathrm{H}+\mathrm{R})$ cause a marked reduction of the amounts of viable cells. This effect was antagonized by RLX, given either $24 \mathrm{~h}$ before hypoxia $(\mathrm{RLX}+\mathrm{H} ; \mathrm{RLX}+\mathrm{H}+\mathrm{R})$ or at reoxygenation $(\mathrm{H}+\mathrm{RLX}+\mathrm{R})$, whereas iRLX had no effects. Representative phase contrast micrographs of $\mathrm{H} 9 \mathrm{c} 2$ cell monolayers $(C)$ showing a marked reduction of cell amounts, as well as cell shrinkage and detachment, on hypoxia $(\mathrm{H})$ and $\mathrm{H}+\mathrm{R}$, whereas RLX reversed these effects. The cytoprotective effects of RLX were significantly reduced by the Notch-1 inhibitor DAPT. Scale bars, $20 \mu \mathrm{m}$. Replicates of the experiments $(n)$ are indicated at the bottom of each column. Values are mean \pm SEM. Significance of differences for trypan blue assay: ${ }^{\mathrm{a}} P<0.001$ vs. control; ${ }^{\mathrm{b}} P<0.001$ vs. $\mathrm{H} ;{ }^{\mathrm{c}} P<0.001$ vs. H+RLX; ${ }^{\mathrm{d}} P<0.001$ vs. control and $P<0.05$ vs. $\mathrm{H} ;{ }^{\mathrm{e}} P<0.001$ vs. $\mathrm{H}+\mathrm{R} ;{ }^{\mathrm{f}} P<0.001$ vs. $\mathrm{RLX}+\mathrm{H}+\mathrm{R} ;{ }^{\mathrm{g}} P<0.001$ vs. $\mathrm{H}+\mathrm{R} ; \mathrm{h}, P<0.001$ vs. $\mathrm{H}+\mathrm{RLX}+\mathrm{R}$. Significance of differences for MTT assay: ${ }^{\mathrm{a}} P<0.001$ vs. control; ${ }^{\mathrm{b}} P<0.01$ vs. $\mathrm{H} ;{ }^{\mathrm{c}} P<0.05$ vs. $\mathrm{H}+\mathrm{RLX} ;{ }^{\mathrm{d}} P<0.001$ vs. control and $P<0.01$ vs. $\mathrm{H} ;{ }^{\mathrm{e}} P<0.01$ vs. $\mathrm{H}+\mathrm{R}$; ${ }^{\mathrm{f}} P<0.05$ vs. $\mathrm{RLX}+\mathrm{H}+\mathrm{R} ;{ }^{\mathrm{g}} P<0.01$ vs. $\mathrm{H}+\mathrm{R} ;{ }^{\mathrm{h}} P<0.05$ vs. $\mathrm{H}+\mathrm{RLX}+\mathrm{R}$. 
4.0.2 image analysis program (Scion Corporation) in 20 ROI of $100 \mu \mathrm{m}^{2}$ for each confocal stacks (at least 10).

\section{Statistical analysis}

The reported data are expressed as the mean \pm SEM of at least 3 independent experiments. As the experimental values in each group approximated to a normal distribution, statistical comparison of differences between groups was carried out using oneway ANOVA followed by the Student-Newman-Keuls multiple comparison test. $P \leq 0.05$ was considered significant. Calculations were done using the GraphPad Prism 2.0 statistical program (GraphPad Software, San Diego, CA, USA).

\section{RESULTS}

\section{RLX receptor is expressed by cardiac muscle cells}

Primary mouse cardiomyocytes were previously found to express RXFP1 (34). The present findings show that rat cardiac muscle H9c2 cells also expressed RXFP1 mRNA (Fig. 1).

\section{RLX increases cardiac muscle cell viability impaired by $\mathbf{H}+\mathrm{R}$}

The Trypan blue exclusion test (Fig. 2A) showed that hypoxia and especially reoxygenation caused a marked reduction of $\mathrm{H} 9 \mathrm{c} 2$ cell viability $(20 \pm 1 \%$ and $10 \pm 2 \%$ viable cells, respectively, the controls being $98 \pm 1 \%: P<$ $0.001)$. RLX (17 nmol/L), added to the culture medium $24 \mathrm{~h}$ before hypoxia, significantly increased cell viability both after hypoxia $(60 \pm 1 \%$ viable cells, $P<0.001)$ and after reoxygenation $(48 \pm 1 \%$ viable cells, $P<0.001$ ) RLX also had protective effects when added at reoxygenation ( $41 \pm 2 \%$ viable cells, $P<0.001)$. The beneficial effects of RLX were significantly reduced, albeit not abolished, when the Notch-1 inhibitor DAPT was administered together with the hormone, indicating that Notch-1 signaling is involved in the cardioprotective role of RLX against cardiac injury (Fig. 2A).

Similar findings were obtained with the MTT assay (Fig. $2 B$ ), which showed that hypoxia and reoxygenation caused a marked reduction of $\mathrm{H} 9 \mathrm{c} 2$ cell viability $(360 \pm 18$ and $184 \pm 17$ OD, respectively, the controls being $1060 \pm 60$ OD; $P<0.001)$. RLX $(17 \mathrm{nmol} / \mathrm{L})$, added $24 \mathrm{~h}$ before hypoxia, significantly increased cell viability both after hypoxia $(511 \pm 31 \mathrm{OD}, P<0.01)$ and after reoxygenation $(325 \pm 31 \mathrm{OD}, P<0.05)$. RLX also had protective effects when added at reoxygenation (313 $\pm 17 \mathrm{OD}, P<0.05)$. iRLX substituted for authentic RLX resulted in the disappearance of any cytoprotective effect, as evaluated by the MTT assay on H9c2 cells (Fig. 2B). The RLX-induced cytoprotection plateaued above $17 \mathrm{nmol} / \mathrm{L}$, showed an estimated $\mathrm{EC}_{50}$ of $4.7 \mathrm{nmol} / \mathrm{L}$, and weakened at higher concentrations, although it was still present at $50 \mathrm{nmol} / \mathrm{L}$.

Light microscopic observation of $\mathrm{H} 9 \mathrm{c} 2$ cell monolayers confirmed the above findings (Fig. 2C): in fact, the cell amounts were markedly reduced and the individual cell morphology worsened by hypoxia and $\mathrm{H}+\mathrm{R}$, whereas RLX reversed the adverse effects. Coadministration of DAPT reduced the effects of RLX.
The cardioprotective action of RLX against hypoxiaand $\mathrm{H}+\mathrm{R}$-induced cell death was confirmed in parallel experiments with primary cultures of mouse neonatal cardiomyocytes subjected to Trypan blue exclusion and MTT assays, which gave similar results as those performed on H9c2 cells (Fig. $3 A-B)$.

\section{RLX protects cardiac muscle cells from nitroxidative damage induced by $\mathrm{H}+\mathrm{R}$}

RLX increased H9c2 cell viability by reducing nitroxidative stress occurring at reoxygenation (Fig. 4). In fact, the levels of immunoreactive NT, a marker of protein nitration that was enhanced on $\mathrm{H}+\mathrm{R}(124 \pm 2 \mathrm{OD}$, the controls being $95 \pm 1$ OD: $P<0.001$ ), were significantly reduced after the addition of RLX, either before hypoxia $(112 \pm 1$ OD: $P<0.001)$ or, at a lesser extent, at
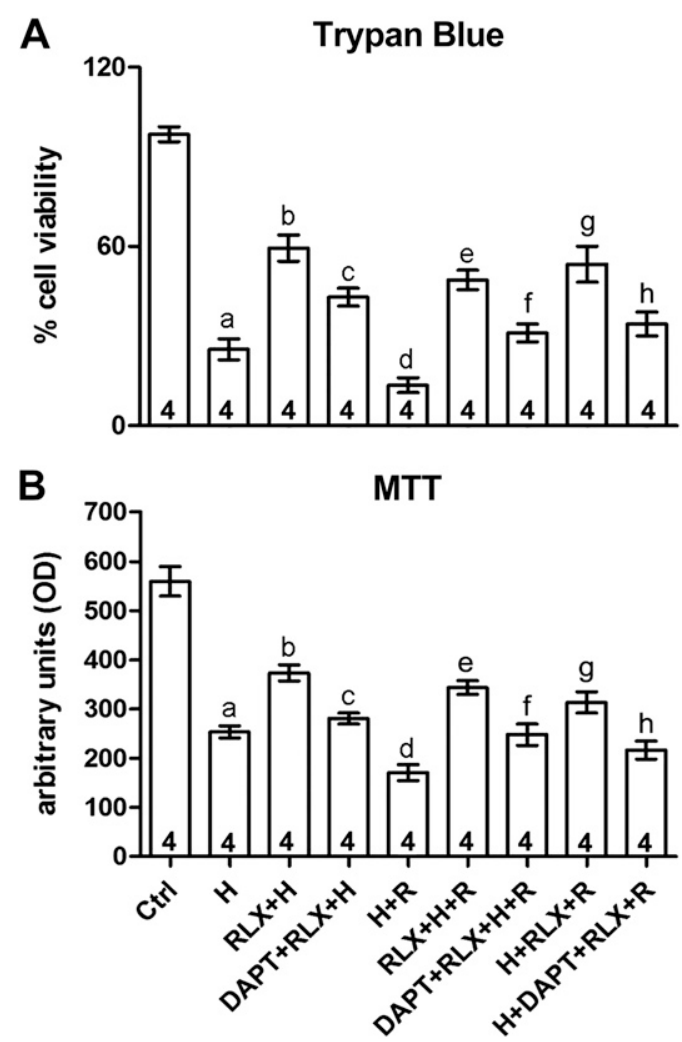

Figure 3. Evaluation of the viability of mouse cardiomyocytes in primary culture by trypan blue exclusion $(A)$ and MTT $(B)$ assay. Hypoxia $(\mathrm{H})$ and even more reoxygenation $(\mathrm{H}+\mathrm{R})$ cause a marked reduction of the amounts of viable cells. This effect was antagonized by RLX, given either $24 \mathrm{~h}$ before hypoxia $(\mathrm{RLX}+\mathrm{H} ; \mathrm{RLX}+\mathrm{H}+\mathrm{R})$ or at reoxygenation $(\mathrm{H}+\mathrm{RLX}+\mathrm{R})$. The cytoprotective effect of RLX was significantly reduced by the Notch-1 inhibitor DAPT. Replicates of the experiments $(n)$ are indicated at the bottom of each column. Values are mean \pm SEM. Significance of differences for trypan blue assay: ${ }^{\mathrm{a}} P<0.001$ vs. control; ${ }^{\mathrm{b}} P<0.001$ vs. $\mathrm{H} ;{ }^{\mathrm{c}} P<0.01$ vs. $\mathrm{H}+\mathrm{RLX} ;{ }^{\mathrm{d}} P<0.001$ vs. control and $P<0.05$ vs. $\mathrm{H}$; ${ }^{\mathrm{e}} P<0.001$ vs. $\mathrm{H}+\mathrm{R}$; ${ }^{\mathrm{f}} P<0.01$ vs. $\mathrm{RLX}+\mathrm{H}+\mathrm{R}$; ${ }^{\mathrm{g}} P<0.001$ vs. $\mathrm{H}+\mathrm{R} ;{ }^{\mathrm{h}} P<0.05$ vs. $\mathrm{H}+\mathrm{RLX}+\mathrm{R}$. Significance of differences for MTT assay: ${ }^{\mathrm{a}} P<0.001 \mathrm{vs}$. control; ${ }^{\mathrm{b}} P<0.01 \mathrm{vs}$. $\mathrm{H} ;{ }^{c} P<0.01$ vs. H+RLX; ${ }^{\mathrm{d}} P<0.001$ vs. control and $P<0.01$ vs. $\mathrm{H}$; ${ }^{\mathrm{e}} P<0.001$ vs. $\mathrm{H}+\mathrm{R} ;{ }^{\mathrm{f}} P<0.01$ vs. $\mathrm{RLX}+\mathrm{H}+\mathrm{R}$; ${ }^{\mathrm{g}} P<0.01$ vs. $\mathrm{H}+\mathrm{R}$; ${ }^{\mathrm{h}} P<0.05$ vs. H+RLX+R. 

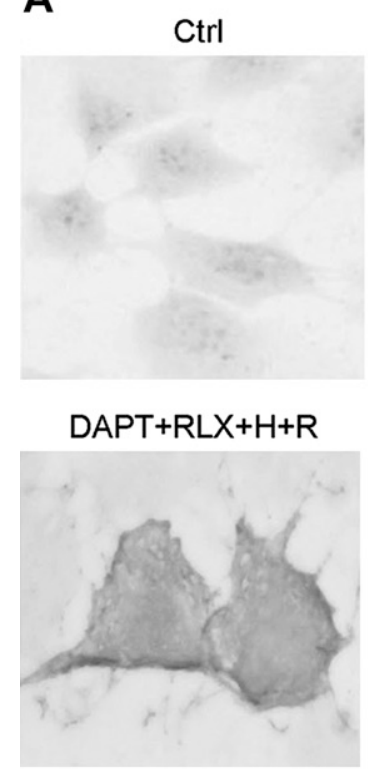
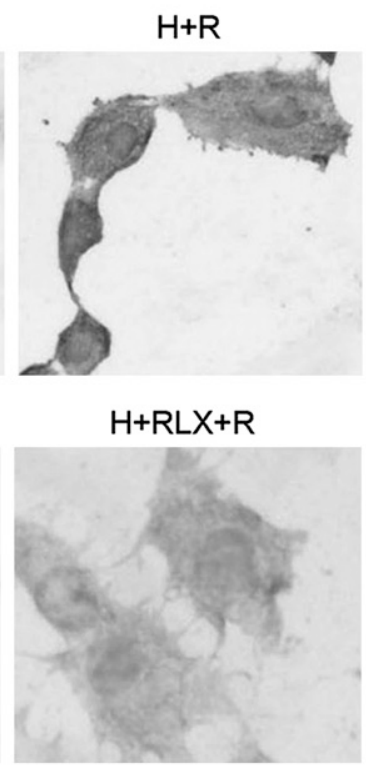

$\mathrm{RLX}+\mathrm{H}+\mathrm{R}$

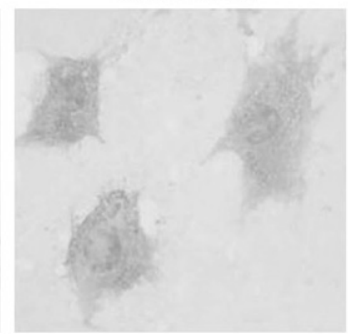

$H+D A P T+R L X+R$

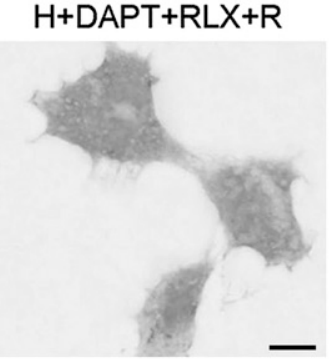

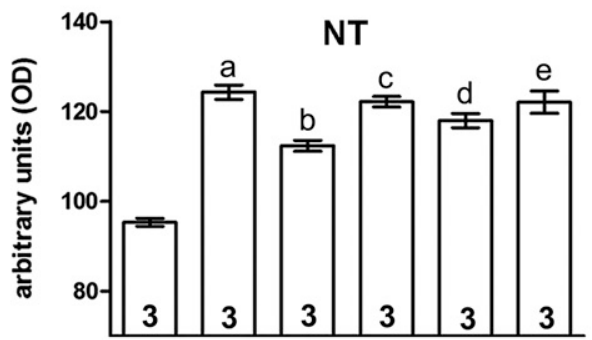

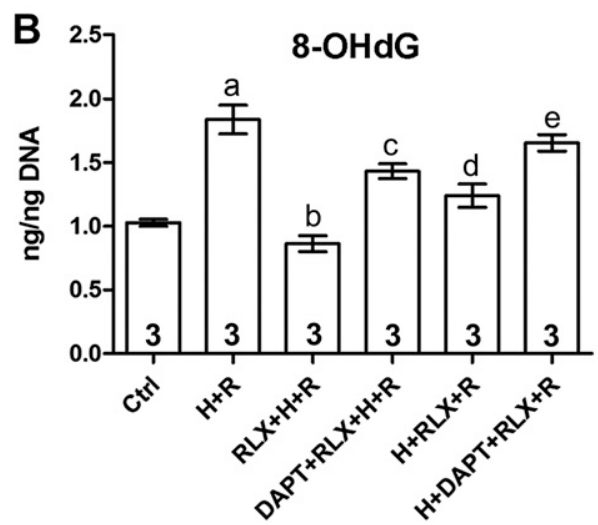

Figure 4. Evaluation of nitroxidative stress markers expressed by H9c2 cells in the different experimental conditions. Immunoreactive nitrotyrosine $(A)$, an index of protein nitration, and $8-\mathrm{OHdG}(B)$, an index of DNA oxidation, were enhanced on $\mathrm{H}+\mathrm{R}$ and significantly reduced by the addition of RLX, given either $24 \mathrm{~h}$ before hypoxia (RLX+H+R) or at reoxygenation (H+RLX+R). The protective effect of RLX was significantly reduced by the Notch-1 inhibitor DAPT. Scale bars, $10 \mu \mathrm{m}$. Replicates of the experiments $(n)$ are indicated at the bottom of each column. Values are mean \pm SEM. Significance of differences for nitrotyrosine: ${ }^{\mathrm{a}} P<0.001$ vs. control; ${ }^{\mathrm{b}} P<0.001$ vs. $\mathrm{H}+\mathrm{R} ;{ }^{\mathrm{c}} P<0.001$ vs. RLX+H+R; ${ }^{\mathrm{d}} P<0.05$ vs. $\mathrm{H}+\mathrm{R} ;{ }^{\mathrm{e}} P<0.05$ vs. H+RLX+R. Significance of differences for $8-\mathrm{OHdG}$ : ${ }^{\mathrm{a}} P<0.01$ vs. control; ${ }^{\mathrm{b}} P<0.001$ vs. $\mathrm{H}+\mathrm{R} ;{ }^{\mathrm{c}} P<0.01$ vs. $\mathrm{RLX}+\mathrm{H}+\mathrm{R} ;{ }^{\mathrm{d}} P<0.01$ vs. $\mathrm{H}+\mathrm{R} ;{ }^{\mathrm{e}} P<0.05$ vs. $\mathrm{H}+\mathrm{RLX}+\mathrm{R}$.

reoxygenation (118 \pm 2 OD: $P<0.05)$ (Fig. $4 A)$. Similar findings were observed in the experiments performed to quantify oxidized DNA. The levels of 8 -OHdG were enhanced on $\mathrm{H}+\mathrm{R}(1.8 \pm 0.1 \mathrm{ng} / \mathrm{ng} \mathrm{DNA}$, the controls being $1 \pm 0.02 \mathrm{ng} / \mathrm{ng}$ DNA: $P<0.01)$ and were significantly reduced after the addition of RLX, either before hypoxia $(0.9 \pm 0.1 \mathrm{ng} / \mathrm{ng}$ DNA: $P<0.001)$ or, at a lesser extent, at reoxygenation $(1.2 \pm 0.1 \mathrm{ng} / \mathrm{ng}$ DNA: $P$ $<0.01$ ) (Fig. 4B). Of interest, the protective effects of RLX against oxidative stress were reduced by DAPT coadministration (Fig. $4 A-B$ ).

\section{RLX protects cardiac muscle cells from apoptosis induced by $\mathrm{H}+\mathrm{R}$}

RLX significantly decreased apoptotic death induced by hypoxia and reoxygenation in $\mathrm{H} 9 \mathrm{c} 2$ cells. Indeed, compared with the controls, mRNA expression of the antiapoptotic gene bcl2 was reduced and that of the proapoptotic gene bax enhanced by hypoxia and, even more, by reoxygenation (Fig. 5). RLX, given both before ischemia and at reperfusion, increased the expression of bcl2 and decreased that of bax. The effects of RLX were reduced by coadministration of DAPT (Fig. 5). Evaluation of the percentage of TUNEL-positive apoptotic cells was consistent with these findings (Fig. 6). Hypoxia and especially reoxygenation caused a marked increase of apoptosis (33 $\pm 3 \%$ and $65 \pm 3 \%$ apoptotic cells, respectively, the controls being $2.2 \pm 0.1 \%: P<0.001)$. RLX $(17 \mathrm{nmol} / \mathrm{L})$, added to the culture medium $24 \mathrm{~h}$ before hypoxia, significantly decreased apoptosis both after hypoxia (23 $\pm 3 \%$ apoptotic cells, $P<0.001)$ and after reoxygenation (38 $\pm 4 \%$ apoptotic cells, $P<0.001$ ). RLX also had protective effects when added at reoxygenation ( $48 \pm 2 \%$ apoptotic cells, $P<0.001)$. As expected, coadministration of DAPT reduced the effects of RLX (Figs. 5 and 6).

\section{RLX stimulates the Notch-1 signaling pathway}

The above findings indicate that inhibition of the Notch-1 signaling pathway reduces the cardioprotective effects of RLX, suggesting a close functional relationship. Indeed, a 24-h treatment of H9c2 cells with RLX (17 nmol/L) induced a significant increase in Notch-ICD expression (control, 40.9 OD; RLX, 72.3 OD; $P<0.001$ ), the active intracellular fragment of the Notch-1 receptor (Fig. 7A-B). As expected, DAPT significantly reduced the basal expression of Notch-ICD (11.8 OD; $P<0.001)$ (Fig. $7 A-B)$. Of note, in the current experimental conditions, NotchICD was down-regulated by hypoxia and, even more, by reoxygenation (Fig. $7 C-D$ ), whereas RLX, given either $24 \mathrm{~h}$ before hypoxia or at reoxygenation, antagonized such an effect (Fig. $7 C-D$ ).

\section{DISCUSSION}

Identification of the endogenous mechanisms that the heart puts into play to increase its resistance to adverse 

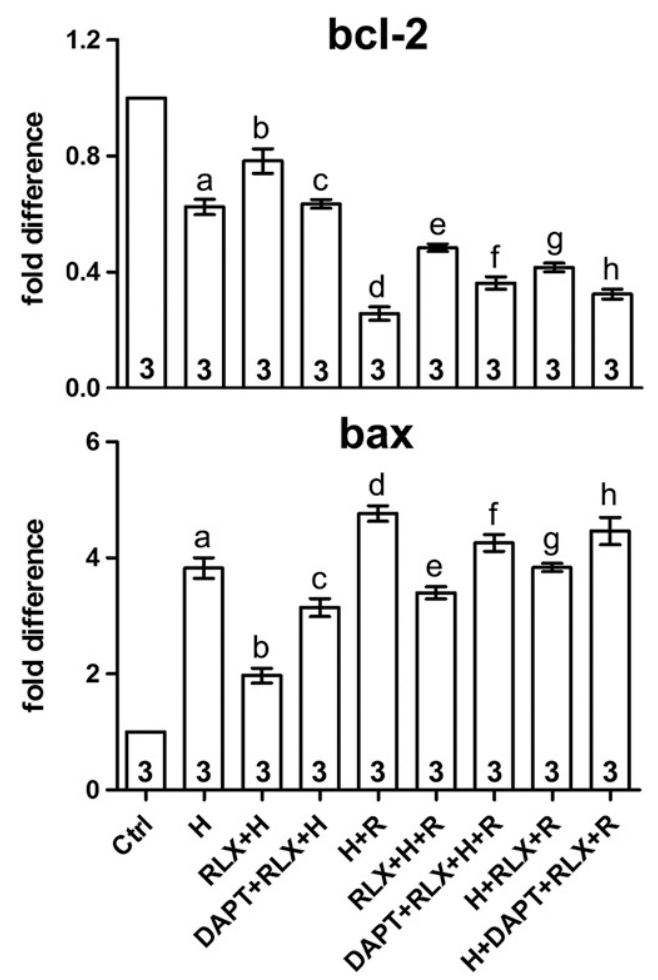

Figure 5. Evaluation of apoptosis-related genes expressed by $\mathrm{H} 9 \mathrm{c} 2$ cells in the different experimental conditions. Real-time PCR shows that the mRNA expression of the antiapoptotic gene bcl2 was reduced and that of the proapoptotic gene bax was enhanced by hypoxia $(\mathrm{H})$ and even more reoxygenation $(\mathrm{H}+\mathrm{R})$. These changes were antagonized by RLX, given either $24 \mathrm{~h}$ before hypoxia $(\mathrm{RLX}+\mathrm{H} ; \mathrm{RLX}+\mathrm{H}+\mathrm{R})$ or at reoxygenation $(\mathrm{H}+\mathrm{RLX}+\mathrm{R})$. The Notch-1 inhibitor DAPT reduced the effects of RLX. The columns represent fold changes over the corresponding values of the control cultures, assumed as 1 . Replicates of the experiments $(n)$ are indicated at the bottom of each column. Values are mean \pm SEM. Significance of differences for bcl-2: ${ }^{\mathrm{a}} P<0.001$ vs. control; ${ }^{\mathrm{b}} P<0.01$ vs. $\mathrm{H} ;{ }^{\mathrm{c}} P<0.01$ vs. H+RLX; ${ }^{\mathrm{d}} P<0.001$ vs. control and $P<0.001$ vs. $\mathrm{H}$; ${ }^{\mathrm{e}} P<0.001$ vs. $\mathrm{H}+\mathrm{R}$; ${ }^{\mathrm{f}} P<0.01$ vs. $\mathrm{RLX}+\mathrm{H}+\mathrm{R} ;{ }^{\mathrm{g}} P<0.01$ vs. $\mathrm{H}+\mathrm{R} ;{ }^{\mathrm{h}} P<0.05$ vs. $\mathrm{H}+\mathrm{RLX}+\mathrm{R}$. Significance of differences for bax: ${ }^{\mathrm{a}} P<0.001$ vs. control; ${ }^{\mathrm{b}} P<$ 0.001 vs. $\mathrm{H} ;{ }^{\mathrm{c}} P<0.001$ vs. $\mathrm{H}+\mathrm{RLX} ;{ }^{\mathrm{d}} P<0.001$ vs. control and $P<0.05$ vs. $\mathrm{H} ;{ }^{\mathrm{e}} P<0.001$ vs. $\mathrm{H}+\mathrm{R} ;{ }^{\mathrm{f}} P<0.01$ vs. $\mathrm{RLX}+\mathrm{H}+\mathrm{R}$; ${ }^{\mathrm{g}} P<0.01$ vs. $\mathrm{H}+\mathrm{R} ;{ }^{\mathrm{h}} P<0.05$ vs. $\mathrm{H}+\mathrm{RLX}+\mathrm{R}$.

conditions represents a new frontier of cardiologic research. In this context, agents capable of modulating these mechanisms to improve myocardial rescue on an ischemic insult can be a promising therapeutic approach (40). Among such agents, RLX deserves a pivotal place. Convincing evidence exists in the literature that RLX, which has been credited as a cardiotropic hormone (7-9), protects the heart from ischemia and reperfusioninduced myocardial damage in ex vivo and in vivo models through its vasodilator, anti-inflammatory, and antifibrotic actions (15-23). The current findings provide the first information that RLX also has a direct cytoprotective effect on cardiac muscle cells subjected in vitro to hypoxia and reoxygenation, increasing their resistance to oxygen deprivation and nitroxidative stress. This finding is in keeping with the observation that RLX protects cardiomyocytes against oxidative stress-induced apoptosis (27).
The RLX-induced protection was observed both in H9c2 cells, a cardiac muscle lineage currently used as a model for ischemic injury, and in primary cultures of freshly isolated ventricular cardiomyocytes. In particular, our findings demonstrate that the protective action of RLX is receptor specific, because it is completely abolished by iRLX and involves the activation of the Notch-1 signaling pathway. Notch-1 is implicated in cardiac development, where it regulates cardiomyocyte proliferation, myocardial trabeculation, and valve formation $(41,42)$, as well as in the maintenance of adult heart tissue integrity (43-45). Notch signaling also plays a role in heart disease: its expression increases in myocardial infarction $(46,47)$ and in dilated or hypertrophic cardiomyopathy (48). Notch-1 activation contributes to cardioprotection afforded by ischemic pre- and postconditioning and in the reduction of ischemia/reperfusion-induced cardiac nitroxidative stress in in vitro and in vivo animal models (28-30). The present findings indicate that H9c2 cardiac muscle cells, which express the high affinity RLX receptor RXFP1, respond to RLX by up-regulating the expression of NotchICD, the active intracellular domain of Notch-1. Indeed, Notch-1 activation requires its proteolytic cleavage by ADAM metalloproteases and $\gamma$-secretase, causing the release of Notch-ICD, which translocates into the nucleus and stimulates the transcription of target genes controlling cell proliferation and maturation (49). In the present experimental conditions, Notch-ICD expression was markedly decreased in hypoxic and $\mathrm{H}+\mathrm{R}$-exposed $\mathrm{H} 9 \mathrm{c} 2$ cells. RLX, added either $24 \mathrm{~h}$ before hypoxia or at reoxygenation, was capable of significantly reducing the Notch-ICD down-regulation. This mechanism plays a major role in the cytoprotective action of RLX on cardiac muscle cells. In fact, the capability of RLX to increase cell viability by reducing $\mathrm{H}+\mathrm{R}$-dependent oxidative stress and apoptosis is significantly hampered by coadministration of DAPT, a $\gamma$-secretase inhibitor that blocks the generation of Notch-ICD (31). The fact that DAPT does not completely abolish the effects of RLX may suggest that multiple cytoprotective signaling pathways are operated by RLX in cardiac muscle cells. For instance, these pathways may involve the endogenous generation of nitric oxide, a typical downstream effector of RLX (50), which has been demonstrated to protect cardiomyocytes from $\mathrm{H}+\mathrm{R}$-induced apoptosis (51). The possible mechanisms by which RLX can activate the Notch-1 pathway remain to be elucidated. It can be speculated that RLX may induce ADAM 10 activation through a dual pathway that involves the upregulation of Akt, a downstream pathway of RXFP1 activation (52) also involved in ADAM 10 activation (53), and down-regulation of TIMP-1 (54), a known ADAM 10 inhibitor (55).

We point out that the present findings have been obtained on cultured embryonic and neonatal cardiac muscle cells, which may not exactly behave as adult cardiomyocytes of the heart in vivo. Conversely, this fact may suggest that RLX is capable of preserving viability of the scattered population of cardiac stem cells of the adult heart, favoring their postischemic activation as an attempt to replace damaged cardiomyocytes. In this context, the finding that RLX constitutively activates the Notch-1 pathway in H9c2 cardiac muscle cells may contribute to explain the mechanisms whereby RLX promote neonatal 
Ctrl

$\mathrm{H}$

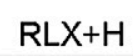

DAPT+RLX+H
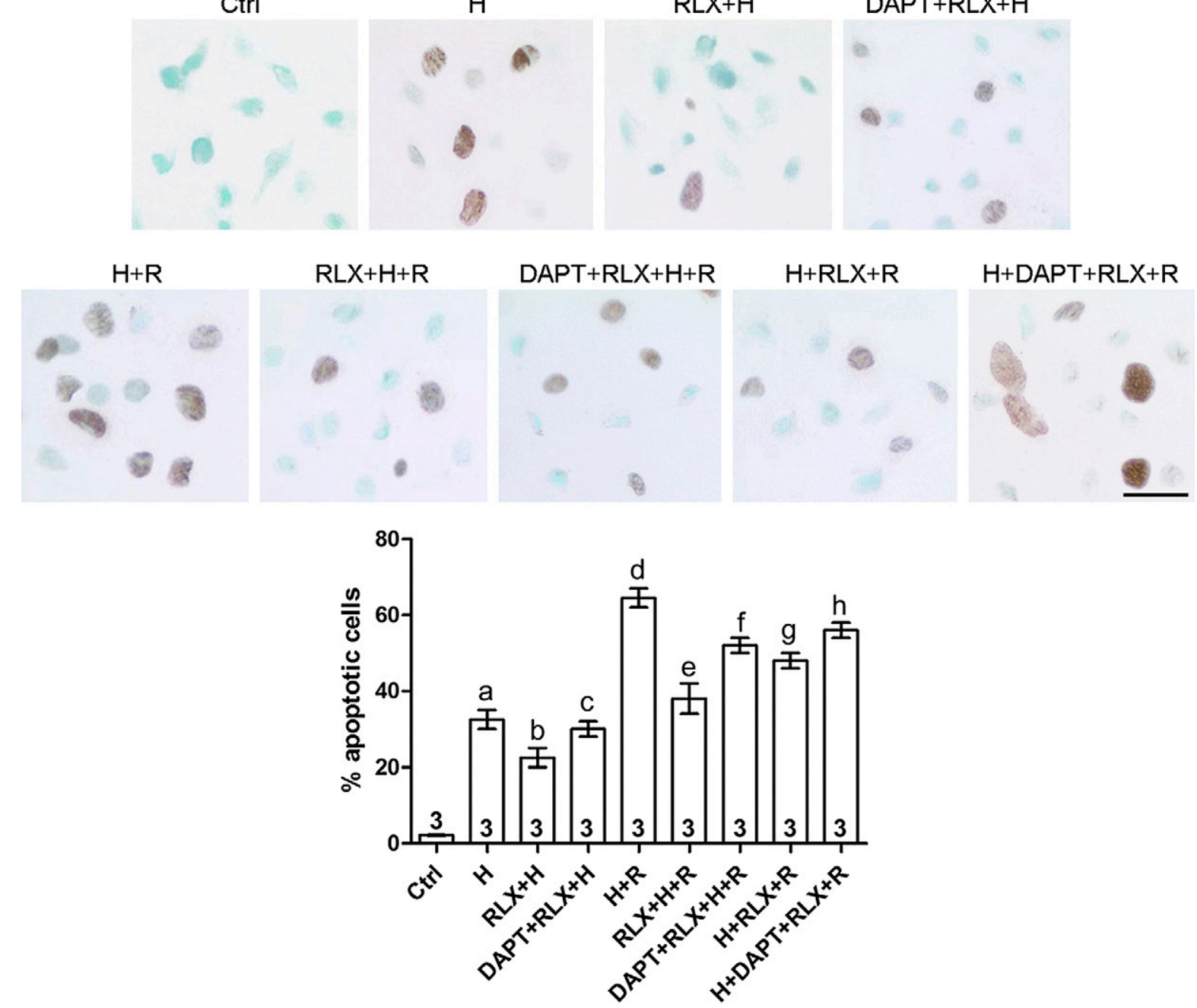

Figure 6. Evaluation of apoptotic H9c2 cells in the different experimental conditions. The percentage of TUNEL-positive cells was increased on hypoxia $(\mathrm{H})$ and reoxygenation $(\mathrm{H}+\mathrm{R})$. These changes were antagonized by RLX, given either $24 \mathrm{~h}$ before hypoxia $(\mathrm{RLX}+\mathrm{H} ; \mathrm{RLX}+\mathrm{H}+\mathrm{R})$ or at reoxygenation $(\mathrm{H}+\mathrm{RLX}+\mathrm{R})$. The Notch-1 inhibitor DAPT reduced the effects of RLX. Scale bars, $10 \mu \mathrm{m}$. Replicates of the experiments $(n)$ are indicated at the bottom of each column. Values are mean \pm SEM. Significance of differences: ${ }^{\mathrm{a}} P<0.001$ vs. control; ${ }^{\mathrm{b}} P<0.05$ vs. $\mathrm{H} ;{ }^{\mathrm{c}} P<0.05$ vs. $\mathrm{H}+\mathrm{RLX} ;{ }^{\mathrm{d}} P<0.001$ vs. control and $P<0.001$ vs. $\mathrm{H} ;{ }^{\mathrm{e}} P<0.001$ vs. H+R; ${ }^{\mathrm{f}} P<0.01$ vs. $\mathrm{RLX}+\mathrm{H}+\mathrm{R} ;{ }^{\mathrm{g}} \mathrm{P}<0.01$ vs. $\mathrm{H}+\mathrm{R} ;{ }^{\mathrm{h}} P<0.05$ vs. $\mathrm{H}+\mathrm{RLX}+\mathrm{R}$.

cardiomyocyte growth and maturation (33). In fact, previous reports have shown that Notch-1 induces cell cycle re-entry and proliferation of cardiac muscle cells $(43,44)$. However, whether RLX may also be cardioprotective through the recruitment of cardiac muscle precursors in the postinfarcted heart remains a stimulating matter for further investigation.

Our findings indicate that the cytoprotection afforded by RLX is more potent when the hormone was added before the occurrence of hypoxia than at the onset of reoxygenation. This notion, taken together with the previous reports that cardiomyocytes produce RLX (10) and express specific RLX receptors $(11,12)$, strongly suggests that RLX could be an endogenous cardiac factor involved in the mechanisms of myocardial preconditioning. Further clues in support to this hypothesis come from the observations that plasma RLX is increased in patients with cardiac failure (56), suggesting that RLX may be released from the injured heart as an attempt to compensate for noxious conditions; and
Notch-1 signaling has been recognized as a major endogenous mechanism involved in heart pre- and postconditioning $(28,29)$. Nonetheless, RLX also exerted a significant cytoprotective action when administered at reoxygenation, suggesting that it can effectively counteract the acute cellular mechanisms of reperfusion injury.

In conclusion, our study expands the knowledge of the pharmacological properties of RLX as a cardioprotective agent. Of note, phase 3 clinical trials performed on heart failure patients have demonstrated that human recombinant RLX, or serelaxin (Novartis, Basel, Switzerland), significantly improved the hemodynamic parameters and life expectancy of the treated patients compared with the placebo group (57), thus emerging as a new drug for the treatment of the failing heart. The existing experimental background can justify the design of clinical trials to explore whether RLX may be a new drug for the primary and secondary prevention and therapy of ischemic heart disease. 
A
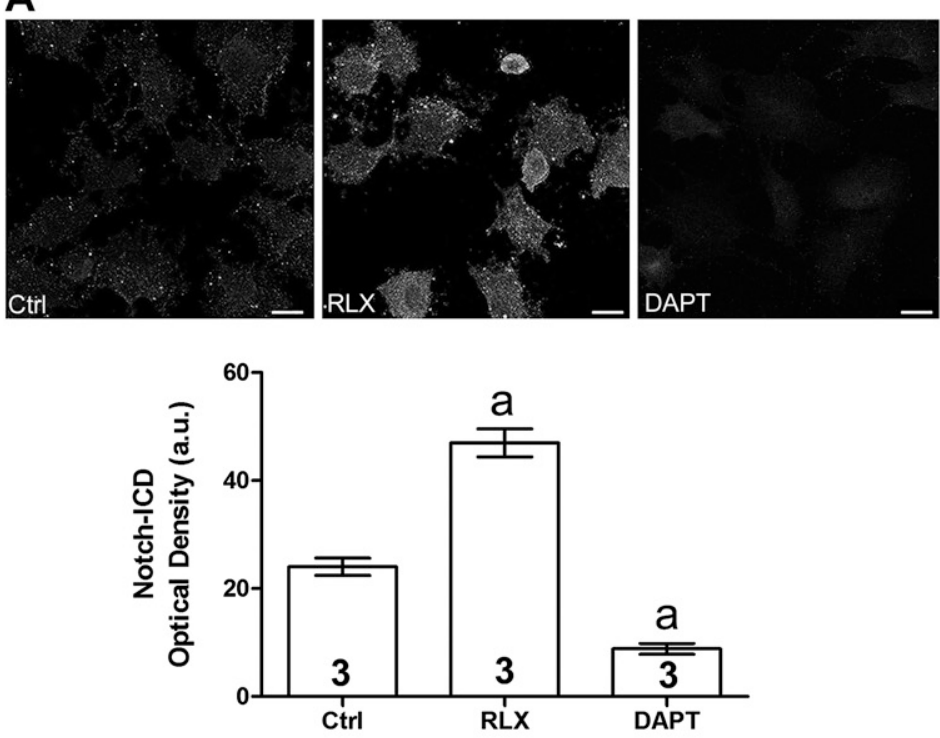

C
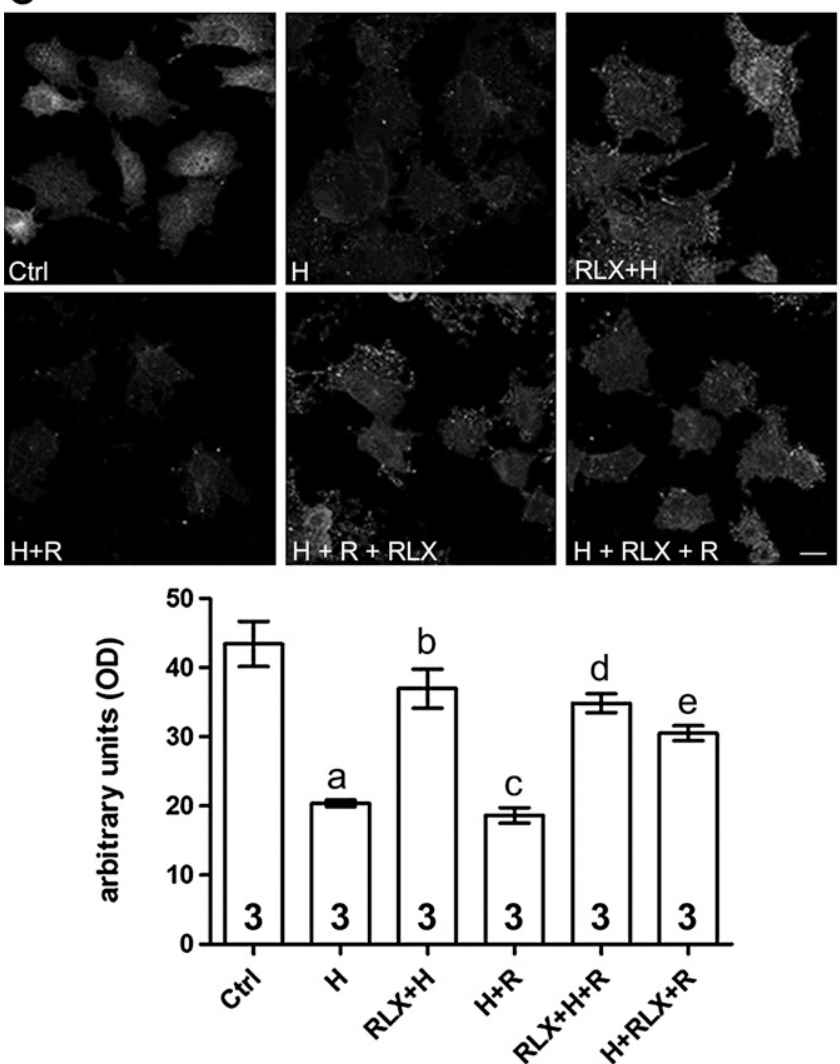

B

Ctrl Ctrl RLX RLX DAPT DAPT

Notch-ICD

GAPDH

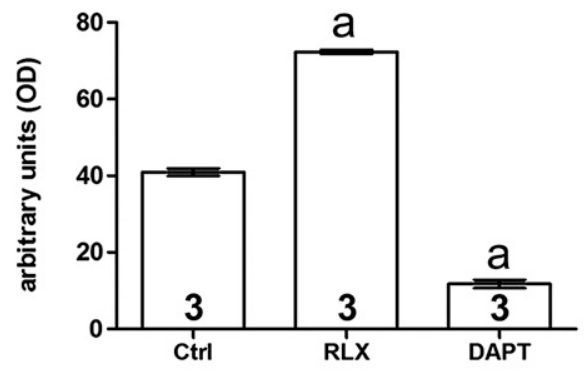

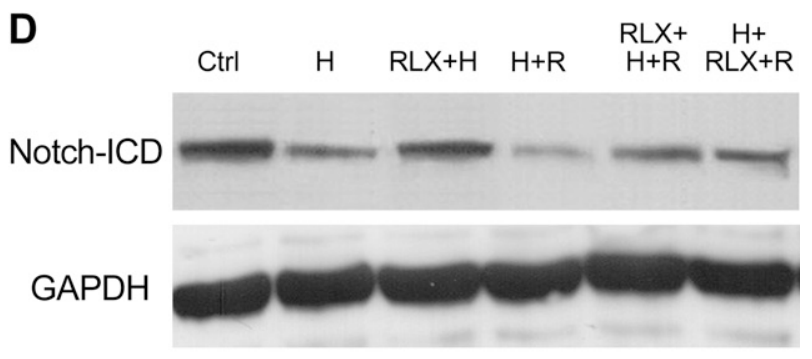

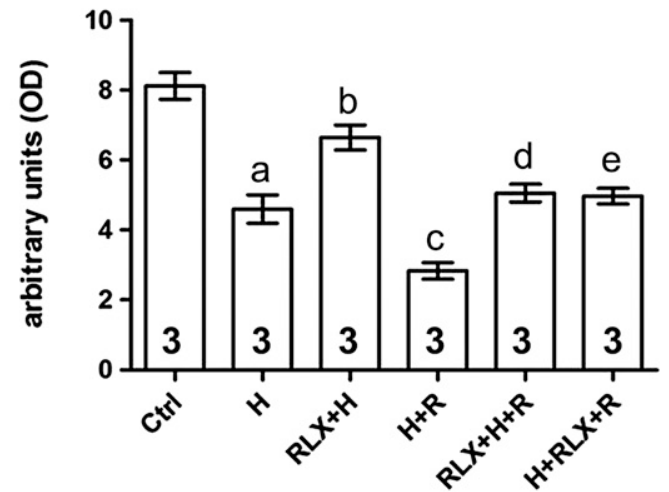

Figure 7. Notch-1 activation by RLX in H9c2 cells under the different experimental conditions. RLX induces a significant increase in Notch-ICD, as revealed by confocal immunofluorescence $(A)$ and Western blotting $(B)$. DAPT caused a significant decrease of NotchICD compared with the controls $(A-B)$. Confocal immunofluorescence $(C)$ and Western blotting analyses $(D)$ also show that NotchICD was down-regulated by hypoxia and, even more, by reoxygenation, whereas RLX, given either $24 \mathrm{~h}$ before hypoxia or at reoxygenation, antagonized such an effect. Scale bar, $10 \mu \mathrm{m}$. Replicates of the experiments $(n)$ are indicated at the bottom of each column. Values are mean \pm sem. Significance of differences: $A, B){ }^{\mathrm{a}} P<0.001 \mathrm{vs}$. control; $C$ ) ${ }^{\mathrm{a}} P<0.001$ vs. control; ${ }^{\mathrm{b}} P<0.001$ vs. $\mathrm{H}$; ${ }^{\mathrm{c}} P<0.001$ vs. control and $P<0.05$ vs. $\mathrm{H} ;{ }^{\mathrm{d}} P<0.001$ vs. $\mathrm{H}+\mathrm{R} ;{ }^{\mathrm{e}} P<0.05$ vs. $\left.\mathrm{H}+\mathrm{R} ; D\right){ }^{\mathrm{a}} P<0.01$ vs. control; ${ }^{\mathrm{b}} P<0.05$ vs. $\mathrm{H} ;{ }^{\mathrm{c}} P<0.001$ vs. control and $P<0.01$ vs. $\mathrm{H} ;{ }^{\mathrm{d}} P<0.05$ vs. $\mathrm{H}+\mathrm{R} ;{ }^{\mathrm{e}} P<0.01$ vs. $\mathrm{H}+\mathrm{R}$. 
The authors thank Dr. Valentina Spinelli for skillful technical help in real-time PCR. This work was supported by funds from the University of Florence issued to S.N.

\section{REFERENCES}

1. Gersh, B. J., Sliwa, K., Mayosi, B. M., and Yusuf, S. (2010) Novel therapeutic concepts: the epidemic of cardiovascular disease in the developing world: global implications. Eur. Heart J. 31, 642-648

2. McCord, J. M. (1985) Oxygen-derived free radicals in postischemic tissue injury. N. Engl. J. Med. 312, 159-163

3. Simpson, P. J., Fantone, J. C., and Lucchesi, B. R. (1988) Myocardial ischemia and reperfusion injury: oxygen radicals and the role of the neutrophil, in Oxygen Radicals and Tissue Injury (Halliwell B, ed). Proceedings of an Upjohn Symposium, pp 63-77

4. Frangogiannis, N. G., Smith, C. W., and Entman, M. L. (2002) The inflammatory response in myocardial infarction. Cardiovasc. Res. 53, 31-47

5. Eefting, F., Rensing, B., Wigman, J., Pannekoek, W. J., Liu, W. M., Cramer, M. J., Lips, D. J., and Doevendans, P. A. (2004) Role of apoptosis in reperfusion injury. Cardiovasc. Res. 61, 414-426

6. Sherwood, O. D. (2004) Relaxin's physiological roles and other diverse actions. Endocr. Rev. 25, 205-234

7. Bani, D. (1997) Relaxin: a pleiotropic hormone. Gen. Pharmacol. 28, 13-22

8. Dschietzig, T., and Stangl, K. (2002) Relaxin: a pregnancy hormone as a central player of body fluid and circulation homeostasis. Cell. Mol. Life Sci. 59, 1-13

9. Nistri, S., Bigazzi, M., and Bani, D. (2007) Relaxin as a cardiovascular hormone: physiology, pathophysiology and therapeutic promises. Cardiovasc. Hematol. Agents Med. Chem. 5, 101-108

10. Taylor, M. J., and Clark, C. L. (1994) Evidence for a novel source of relaxin: atrial cardiocytes. J. Endocrinol. 143, R5-R8

11. Kompa, A. R., Samuel, C. S., and Summers, R. J. (2002) Inotropic responses to human gene 2 (B29) relaxin in a rat model of myocardial infarction (MI): effect of pertussis toxin. Br. J. Phar macol. 137, 710-718

12. Moore, X. L., Su, Y., Fan, Y., Zhang, Y. Y., Woodcock, E. A., Dart, A. M., and Du, X. J. (2014) Diverse regulation of cardiac expression of relaxin receptor by $\alpha 1$ - and $\beta 1$-adrenoceptors. Cardiovasc. Drugs Ther. 28, 221-228

13. Bani-Sacchi, T., Bigazzi, M., Bani, D., Mannaioni, P. F., and Masini, E. (1995) Relaxin-induced increased coronary flow through stimulation of nitric oxide production. Br. J. Pharmacol. 116, 1589-1594

14. Unemori, E. N., Lewis, M., Constant, J., Arnold, G., Grove, B. H., Normand, J., Deshpande, U., Salles, A., Pickford, L. B., Erikson, M. E., Hunt, T.K., and Huang, X. (2000) Relaxin induces vascular endothelial growth factor expression and angiogenesis selectively at wound sites. Wound Repair Regen. 8, 361-370

15. Bonacchi, M., Nistri, S., Nanni, C., Gelsomino, S., Pini, A., Cinci, L., Maiani, M., Zecchi-Orlandini, S., Lorusso, R., Fanti, S. Silvertown, J., and Bani, D. (2009) Functional and histopathological improvement of the post-infarcted rat heart upon myoblast cell grafting and relaxin therapy. J. Cell. Mol. Med. 13(9B), 3437-3448

16. Nistri, S., Chiappini, L., Sassoli, C., and Bani, D. (2003) Relaxin inhibits lipopolysaccharide-induced adhesion of neutrophils to coronary endothelial cells by a nitric oxide-mediated mechanism. FASEB J. 17, 2109-2111

17. Masini, E., Nistri, S., Vannacci, A., Bani Sacchi, T., Novelli, A., and Bani, D. (2004) Relaxin inhibits the activation of human neutrophils: involvement of the nitric oxide pathway. Endocrinology 145, 1106-1112

18. Perna, A. M., Masini, E., Nistri, S., Briganti, V., Chiappini, L., Stefano, P., Bigazzi, M., Pieroni, C., Bani Sacchi, T., and Bani, D. (2005) Novel drug development opportunity for relaxin in acute myocardial infarction: evidences from a swine model. FASEB J. 19, 1525-1527

19. Samuel, C. S., Unemori, E. N., Mookerjee, I., Bathgate, R. A., Layfield, S. L., Mak, J., Tregear, G. W., and Du, X. J. (2004) Relaxin modulates cardiac fibroblast proliferation, differentiation, and collagen production and reverses cardiac fibrosis in vivo. Endocrinology 145, 4125-4133

20. Samuel, C. S., Cendrawan, S., Gao, X. M., Ming, Z., Zhao, C., Kiriazis, H., Xu, Q., Tregear, G. W., Bathgate, R. A., and Du, X. J.
(2011) Relaxin remodels fibrotic healing following myocardial infarction. Lab. Invest. 91, 675-690

21. Lekgabe, E. D., Kiriazis, H., Zhao, C., Xu, Q., Moore, X. L., Su, Y., Bathgate, R. A., Du, X. J., and Samuel, C. S. (2005) Relaxin reverses cardiac and renal fibrosis in spontaneously hypertensive rats. Hypertension 46, 412-418

22. Formigli, L., Perna, A. M., Meacci, E., Cinci, L., Margheri, M., Nistri, S., Tani, A., Silvertown, J., Orlandini, G., Porciani, C., Zecchi-Orlandini, S., Medin, J., and Bani, D. (2007) Paracrine effects of transplanted myoblasts and relaxin on post-infarction heart remodelling. J. Cell. Mol. Med. 11, 1087-1100

23. Sassoli, C., Chellini, F., Pini, A., Tani, A., Nistri, S., Nosi, D., Zecchi-Orlandini, S., Bani, D., and Formigli, L. (2013) Relaxin prevents cardiac fibroblast-myofibroblast transition via notch-1mediated inhibition of TGF- $\beta /$ Smad3 signaling. PLoS One 21, e63896

24. Masini, E., Bani, D., Bello, M. G., Bigazzi, M., Mannaioni, P. F., and Sacchi, T. B. (1997) Relaxin counteracts myocardial damage induced by ischemia-reperfusion in isolated guinea pig hearts: evidence for an involvement of nitric oxide. Endocrinology 138, 4713-4720

25. Bani, D., Masini, E., Bello, M. G., Bigazzi, M., and Sacchi, T. B. (1998) Relaxin protects against myocardial injury caused by ischemia and reperfusion in rat heart. Am. J. Pathol. 152, $1367-1376$

26. Nistri, S., and Bani, D. (2005) Relaxin in vascular physiology and pathophysiology: possible implications in ischemic brain disease. Curr. Neurovasc. Res. 2, 225-3

27. Moore, X. L., Tan, S. L., Lo, C. Y., Fang, L., Su, Y. D., Gao, X. M., Woodcock, E. A., Summers, R. J., Tregear, G. W., Bathgate, R. A., and $\mathrm{Du}, \mathrm{X} . \mathrm{J}$. (2007) Relaxin antagonizes hypertrophy and apoptosis in neonatal rat cardiomyocytes. Endocrinology 148, $1582-1589$

28. Yu, B., and Song, B. (2014) Notch 1 signalling inhibits cardiomyocyte apoptosis in ischaemic postconditioning. Heart Lung Circ. 23, 152-158

29. Zhou, X. L., Wan, L., Xu, Q. R., Zhao, Y., and Liu, J. C. (2013) Notch signaling activation contributes to cardioprotection provided by ischemic preconditioning and postconditioning. J. Transl. Med. 11, 251

30. Pei, H., Yu, Q., Xue, Q., Guo, Y., Sun, L., Hong, Z., Han, H., Gao, E., Qu, Y., and Tao, L. (2013) Notch1 cardioprotection in myocardial ischemia/reperfusion involves reduction of oxidative/ nitrative stress. Basic Res. Cardiol. 108, 373

31. Brou, C. (2009) Intracellular trafficking of Notch receptors and ligands. Exp. Cell Res. 315, 1549-1555

32. Hescheler, J., Meyer, R., Plant, S., Krautwurst, D., Rosenthal, W., and Schultz, G. (1991) Morphological, biochemical, and electrophysiological characterization of a clonal cell $(\mathrm{H} 9 \mathrm{c} 2)$ line from rat heart. Circ. Res. 69, 1476-1486

33. Nistri, S., Pini, A., Sassoli, C., Squecco, R., Francini, F., Formigli, L., and Bani, D. (2012) Relaxin promotes growth and maturation of mouse neonatal cardiomyocytes in vitro: clues for cardiac regeneration. J. Cell. Mol. Med. 16, 507-519

34. Formigli, L., Francini, F., Nistri, S., Margheri, M., Luciani, G., Naro, F., Silvertown, J. D., Orlandini, S. Z., Meacci, E., and Bani, D. (2009) Skeletal myoblasts overexpressing relaxin improve differentiation and communication of primary murine cardiomyocyte cell cultures. J. Mol. Cell. Cardiol. 47, 335-345

35. Zhang, Z. L., Fan, Y., and Liu, M. L. (2012) Ginsenoside Rg1 inhibits autophagy in H9c2 cardiomyocytes exposed to hypoxia/ reoxygenation. Mol. Cell. Biochem. 365, 243-250

36. Büllesbach, E. E., and Schwabe, C. (1988) On the receptor binding site of relaxins. Int. J. Pept. Protein Res. 32, 361-367

37. Bani, D., Nistri, S., Cinci, L., Giannini, L., Princivalle, M., Elliott, L., Bigazzi, M., and Masini, E. (2007) A novel, simple bioactivity assay for relaxin based on inhibition of platelet aggregation. Regul. Pept. 144, 10-16

38. Prasanna, N., and Rasool, M. (2014) Modulation of geneexpression profiles associated with sodium arsenite-induced cardiotoxicity by p-coumaric acid, a common dietary polyphenol. J. Biochem. Mol. Toxicol. 28, 174-180

39. Cuzzocrea, S., Mazzon, E., Dugo, L., Caputi, A. P., Aston, K., Riley, D. P., and Salvemini, D. (2001) Protective effects of a new stable, highly active SOD mimetic, M40401 in splanchnic artery occlusion and reperfusion. Br. J. Pharmacol. 132, $19-29$ 
40. Della-Morte, D., Guadagni, F., Palmirotta, R., Ferroni, P., Testa, G., Cacciatore, F., Abete, P., Rengo, F., Perez-Pinzon, M. A., Sacco, R. L., and Rundek, T. (2012) Genetics and genomics of ischemic tolerance: focus on cardiac and cerebral ischemic preconditioning. Pharmacogenomics 13, 1741-1757

41. Niessen, K., and Karsan, A. (2007) Notch signaling in the developing cardiovascular system. Am. J. Physiol. Cell Physiol. 293, C1-C11

42. High, F. A., and Epstein, J. A. (2008) The multifaceted role of Notch in cardiac development and disease. Nat. Rev. Genet. 9, 49-61

43. Campa, V. M., Gutiérrez-Lanza, R., Cerignoli, F., Díaz-Trelles, R., Nelson, B., Tsuji, T., Barcova, M., Jiang, W., and Mercola, M. (2008) Notch activates cell cycle reentry and progression in quiescent cardiomyocytes. J. Cell Biol. 183, 129-141

44. Collesi, C., Zentilin, L., Sinagra, G., and Giacca, M. (2008) Notch1 signaling stimulates proliferation of immature cardiomyocytes. J. Cell Biol. 183, 117-128

45. Nemir, M., and Pedrazzini, T. (2008) Functional role of Notch signaling in the developing and postnatal heart. J. Mol. Cell. Cardiol. 45, 495-504

46. Gude, N. A., Emmanuel, G., Wu, W., Cottage, C. T., Fischer, K., Quijada, P., Muraski, J. A., Alvarez, R., Rubio, M., Schaefer, E., and Sussman, M. A. (2008) Activation of Notch-mediated protective signaling in the myocardium. Circ. Res. 102, 1025-1035

47. Kratsios, P., Catela, C., Salimova, E., Huth, M., Berno, V., Rosenthal, N., and Mourkioti, F. (2010) Distinct roles for cellautonomous Notch signaling in cardiomyocytes of the embryonic and adult heart. Circ. Res. 106, 559-572

48. Croquelois, A., Domenighetti, A. A., Nemir, M., Lepore, M., Rosenblatt-Velin, N., Radtke, F., and Pedrazzini, T. (2008) Control of the adaptive response of the heart to stress via the Notch1 receptor pathway. J. Exp. Med. 205, 3173-3185

49. Boni, A., Urbanek, K., Nascimbene, A., Hosoda, T., Zheng, H., Delucchi, F., Amano, K., Gonzalez, A., Vitale, S., Ojaimi, C., et al. (2008) Notch1 regulates the fate of cardiac progenitor cells. Proc. Natl. Acad. Sci. USA 105, 15529-15534
50. Baccari, M. C., and Bani, D. (2008) Relaxin and nitric oxide signalling. Curr. Protein Pept. Sci. 9, 638-645

51. Rakhit, R. D., Kabir, A. N., Mockridge, J. W., Saurin, A., and Marber, M. S. (2001) Role of G proteins and modulation of p38 MAPK activation in the protection by nitric oxide against ischemia-reoxygenation injury. Biochem. Biophys. Res. Commun. 286, 995-1002

52. McGuane, J. T., Debrah, J. E., Sautina, L., Jarajapu, Y. P., Novak, J., Rubin, J. P., Grant, M. B., Segal, M., and Conrad, K. P. (2011) Relaxin induces rapid dilation of rodent small renal and human subcutaneous arteries via PI3 kinase and nitric oxide. Endocrinology 152, 2786-2796

53. Fernandez, J. W., Rezai-Zadeh, K., Obregon, D., and Tan, J. (2010) EGCG functions through estrogen receptor-mediated activation of ADAM10 in the promotion of non-amyloidogenic processing of APP. FEBS Lett. 584, 4259-4267

54. Palejwala, S., Stein, D. E., Weiss, G., Monia, B. P., Tortoriello, D., and Goldsmith, L. T. (2001) Relaxin positively regulates matrix metalloproteinase expression in human lower uterine segment fibroblasts using a tyrosine kinase signaling pathway. Endocrinology 142, 3405-3413

55. Edwards, D. R., Handsley, M. M., and Pennington, C. J. (2008) The ADAM metalloproteinases. Mol. Aspects Med. 29, 258-289

56. Dschietzig, T., Richter, C., Bartsch, C., Laule, M., Armbruster, F. P., Baumann, G., and Stangl, K. (2001) The pregnancy hormone relaxin is a player in human heart failure. FASEB J. 15 , 2187-2195

57. Teerlink, J. R., Cotter, G., Davison, B. A., Felker, G. M., Filippatos, G., Greenberg, B. H., Ponikowski, P., Unemori, E., Voors, A. A., Adams, K. F., Jr., et al; RELAXin in Acute Heart Failure (RELAX-AHF) Investigators. (2013) Serelaxin, recombinant human relaxin-2, for treatment of acute heart failure (RELAX-AHF): a randomised, placebo-controlled trial. Lancet 381, 29-39

Received for publication May 7, 2014 Accepted for publication September 15, 2014. 


\section{THE}

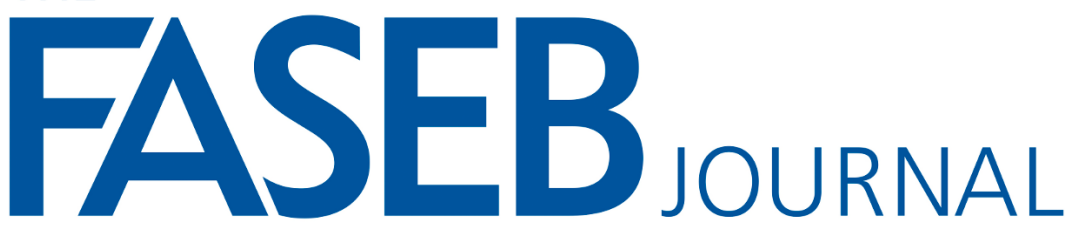

The Journal of the Federation of American Societies for Experimental Biology

\section{Relaxin protects cardiac muscle cells from hypoxia/reoxygenation injury: involvement of the Notch-1 pathway}

Giulia Boccalini, Chiara Sassoli, Lucia Formigli, et al.

FASEB J 2015 29: 239-249 originally published online October 23, 2014 Access the most recent version at doi:10.1096/fj.14-254854

References This article cites 55 articles, 15 of which can be accessed free at: http://www.fasebj.org/content/29/1/239.full.html\#ref-list-1

Subscriptions Information about subscribing to The FASEB Journal is online at http://www.faseb.org/The-FASEB-Journal/Librarian-s-Resources.aspx

Permissions Submit copyright permission requests at:

http://www.fasebj.org/site/misc/copyright.xhtml

Email Alerts Receive free email alerts when new an article cites this article - sign up at http://www.fasebj.org/cgi/alerts 